\title{
Preparation of diagnostic polyclonal and monoclonal antibodies against outer envelope proteins of Serpulina pilosicoli
}

\author{
I. W. M. TENAYA, W. J. PENHALE and D. J. HAMPSON \\ Division of Veterinary and Biomedical Sciences, Murdoch University, Murdoch, Western Australia 6150, \\ Australia
}

\begin{abstract}
The purpose of this study was to prepare specific sera for use in the rapid detection and identification of the intestinal spirochaete Serpulina pilosicoli. In Western blot analysis, with pig antiserum which was raised against whole cells of $S$. pilosicoli and absorbed with outer envelope protein extracts from $S$. hyodysenteriae and $S$. innocens, a prominent protein with $M_{r}$ of $c .72 \mathrm{kDa}$ was consistently identified in outer envelope preparations of $S$. pilosicoli strains. Immunogold labelling demonstrated that this was located on the outer surface of intact $S$. pilosicoli cells. Two monoclonal antibodies (MAbs), designated $\mathrm{C12}$ and M96, were raised against the protein. Although C12 reacted with a protein band of $c .72 \mathrm{kDa}$, this was also present in preparations from strains of other Serpulina spp. examined. MAb M96 reacted with an 80-kDa protein which was present only in preparations made from strains of $S$. pilosicoli. This was used in Western blot analysis and in an immunodot-blot assay with outer envelope extracts to specifically identify $S$. pilosicoli strains isolated from man, pigs, dogs and poultry. An indirect immunofluorescence test with MAb M96 also was used to detect and identify whole $S$. pilosicoli cells. Therefore, both the cross-absorbed antiserum and MAb M96 are potentially useful reagents for the detection and identification of $S$. pilosicoli.
\end{abstract}

\section{Introduction}

There are currently five officially named species of intestinal spirochaetes in the genus Serpulina: $S$. hyodysenteriae, $S$. innocens, S. pilosicoli, $S$. intermedia and $S$. murdochii [1-3]. S. hyodysenteriae is the agent of swine dysentery, a severe mucohaemorrhagic colitis of pigs, and S. pilosicoli was recently named as the causative agent of porcine intestinal spirochaetosis (PIS) [2]. The latter condition is an infection of the caecum and colon, is milder than swine dysentery, and has been recorded in pigs in Australia, North America, Europe and Scandinavia [4-7]. The disease is associated with poor feed efficiency and depressed growth rates $[4,8]$. A striking histological feature which is often seen is the attachment of the spirochaetes by one cell end to the colonic epithelium, forming a dense 'false brush border' $[2,4,8-10]$. This feature is not seen in pigs with swine dysentery. End-on attachment of spirochaetes also has been observed in the large intestine of other host species, including man $[11,12]$, dogs $[13,14]$ and

Received 19 Aug. 1997; accepted 26 Aug. 1997.

Corresponding author: Dr D. J. Hampson.

E-mail: hampson@numbat.murdoch.edu.au poultry $[15,16]$. These organisms - originally isolated from individuals with diarrhoea and intestinal disturbances, and provisionally named 'Anguillina coli' [17] - are now known as $S$. pilosicoli $[18,19]$.

Like other members of the genus, $S$. pilosicoli is anaerobic and takes 3-10 days to grow on selective agar. Once isolated, $S$. pilosicoli strains can be distinguished from other spirochaetes in the genus Serpulina, for example, on the basis of their multilocus enzyme electrophoresis (MEE) profile [17] and their reactivity in a specific polymerase chain reaction that amplifies a 1330-bp sequence of the $16 \mathrm{~S}$ rRNA gene $[18,20]$. Characteristically, $S$. pilosicoli cells also hydrolyse hippurate and use the pentose sugar Dribose as a growth substrate $[2,19,21]$. As it is relatively difficult and time-consuming to isolate and identify the spirochaete, a monoclonal antibody (MAb) specific to a $29-\mathrm{kDa}$ outer envelope protein of $S$. pilosicoli was prepared and characterised in a previous study [22]. Although this MAb could be used in immunofluorescent and Western blot assays, it had the disadvantage that it was of the IgM class. The main purpose of the current study was to identify specific immunogenic outer envelope proteins of $S$. pilosicoli, 
prepare antisera against these and develop the sera for use in the rapid identification of $S$. pilosicoli isolates from man and animals.

\section{Materials and methods}

\section{Bacterial strains and culture conditions}

Twenty-nine strains of anaerobic intestinal spirochaetes were used in this study (Table 1). These were obtained from a collection held at the Reference Centre for Intestinal Spirochaetes, Murdoch University, Western Australia, where their identity had been confirmed by MEE analysis [17, 23]. They included 20 strains of $S$. pilosicoli isolated from pigs $(\mathrm{n}=8)$, man $(\mathrm{n}=8)$, dogs $(\mathrm{n}=2)$ and chickens $(\mathrm{n}=2)$; two strains each of $S$. hyodysenteriae, $S$. innocens, $S$. intermedia and $S$. murdochii, as well as one strain of Brachyspira aalborgi [24]. The organisms were grown for 3-5 days at $37^{\circ} \mathrm{C}$ on a reciprocal shaker in Kunkle's prereduced anaerobic Trypticase Soy Broth (BBL) supplemented with fetal bovine serum $2 \%$ and a $1 \%$ ethanolic cholesterol solution [25], and harvested in mid-log phase $\left(c .10^{8}\right.$ cells $\left./ \mathrm{ml}\right)$.

\section{Preparation of outer envelope proteins}

Outer envelope proteins were extracted from whole spirochaete cells with the detergent Triton $\mathrm{X}-114$, as described previously [22]. Spirochaetes in $300 \mathrm{ml}$ of broth were centrifuged at $2800 \mathrm{~g}$ for $15 \mathrm{~min}$ at $4^{\circ} \mathrm{C}$, resuspended and washed three more times with $0.05 \mathrm{M}$ Tris buffered saline (TBS), containing $1 \mathrm{M} \mathrm{NaCl}, 1 \mathrm{M}$ Tris $(\mathrm{pH} \mathrm{8.0)}$ and resuspended in $30 \mathrm{ml}$ of extraction buffer, comprising Triton X-114 0.1\% v/v, $10 \mathrm{mM}$ Tris and $5 \mathrm{mM}$ EDTA (pH 7.5). The preparation was mixed gently by inversion at $4^{\circ} \mathrm{C}$ for $18 \mathrm{~h}$ and then centrifuged at $20000 \mathrm{~g}$ for $30 \mathrm{~min}$ at $4^{\circ} \mathrm{C}$. The protein in the soluble supernatant fraction was precipitated with 10 volumes of absolute acetone at $-20^{\circ} \mathrm{C}$ for $18 \mathrm{~h}$, and collected by centrifugation at $1000 \mathrm{~g}$ for $10 \mathrm{~min}$ at $4^{\circ} \mathrm{C}$. The pellet was resuspended with phosphate-buffered saline (PBS, $\mathrm{pH}$ 7.2) and its protein concentration was estimated with a commercial protein assay kit (BioRad Laboratories, CA, USA).

\section{SDS-PAGE and Western blotting}

Extracts were boiled for $5 \mathrm{~min}$ in sample-reducing buffer $(0.125 \mathrm{M}$ Tris- $\mathrm{HCl}$, pH 6.8 , SDS $4 \% \mathrm{w} / \mathrm{v}, 2-\beta$ mercaptoethanol $10 \% \mathrm{v} / \mathrm{v}$, glycerol $20 \% \mathrm{v} / \mathrm{v}$ and bromophenol blue $0.001 \% \mathrm{w} / \mathrm{v}$ ) and subjected to SDS-PAGE through $4 \%$ stacking and $12.5 \%$ resolving gels (BioRad Protean and Mini-protean systems). Proteins in the gel were visualised with Coomassie Brilliant Blue R-250 (BioRad), with low $\mathrm{M}_{\mathrm{r}}$ pre-stained markers as standards (BioRad). For Western blot analysis, the separated proteins were transferred

Table 1. Results of testing strains of intestinal spirochaetes with MAb M96

\begin{tabular}{|c|c|c|c|c|c|}
\hline Isolates tested & Strain & Origin* & Western blotting $\dagger$ & Immunodot-blot analysis $\ddagger$ & IFAT \\
\hline \multicolumn{6}{|l|}{ S. pilosicoli } \\
\hline \multirow{8}{*}{ Pig isolates } & 1648 & NSW & + & + & +++ \\
\hline & 3295 & WA & + & + & +++ \\
\hline & Gut $A$ & USA & + & + & ++ \\
\hline & Gut B & USA & + & + & +++ \\
\hline & MIA & UK & + & + & ++ \\
\hline & 883769 & Can & + & + & +++ \\
\hline & 891069 & Can & + & + & ++ \\
\hline & $\mathrm{T} 4527$ & Tas & + & + & ++ \\
\hline \multirow[t]{8}{*}{ Human isolates } & $11 \mathrm{~A}$ & Oman & + & + & ++ \\
\hline & N26 & Oman & + & + & ++ \\
\hline & Gap 183 & Sydney & + & + & +++ \\
\hline & Gap 401 & Sydney & + & + & ++ \\
\hline & HRM IA & Italy & + & + & +++ \\
\hline & HRM 2B & Italy & + & + & ++ \\
\hline & Naomi & WA & + & + & ++ \\
\hline & Disley & WA & + & + & ++ \\
\hline \multirow[t]{2}{*}{ Dog isolates } & 1624294 & USA & + & + & ++ \\
\hline & MeyersK912 & USA & + & + & +++ \\
\hline \multirow[t]{2}{*}{ Chicken isolates } & 42167 & USA & + & + & +++ \\
\hline & Q94035406 & USA & + & + & + \\
\hline \multirow[t]{2}{*}{ S. hyodysenteriae } & B78 & USA & - & - & - \\
\hline & B204 & USA & - & - & - \\
\hline \multirow[t]{2}{*}{ S. innocens } & B256 & USA & - & - & - \\
\hline & $4 / 71$ & UK & - & - & - \\
\hline \multirow[t]{2}{*}{$S$. intermedia } & 889 & NSW & - & - & - \\
\hline & PWSA & UK & - & - & - \\
\hline \multirow[t]{2}{*}{ S. murdochii } & 15521 & WA & - & - & - \\
\hline & Growden & WA & - & - & - \\
\hline Brachyspira aalborgi & ATCC43994 & Denmark & - & - & - \\
\hline
\end{tabular}

*Can, Canada; Tas, Tasmania; NSW, New South Wales; WA, Western Australia.

+ Western blot analysis of outer envelope proteins: - , negative reaction; + , positive reaction.

$\$$ Immunodot-blot analysis of outer envelope proteins: - , negative reaction; + , positive reaction.

§IFAT, indirect fluorescent antibody test: - , negative reaction; + , weak positive reaction; ++ , strong positive reaction; +++ , very strong positive reaction. 
electrophoretically to nitrocellulose membranes (Hybond-C extra, $0.45 \mu \mathrm{m}$ pore size; Amersham, Sydney, Australia), by the method of Towbin et al. [26]. They were treated with appropriate antisera (pig, rabbit or mouse) diluted 1 in 50 in PBS, followed by horseradish peroxidase (HRP)-conjugated goat antiserum raised against immunoglobulins from the appropriate species (BioRad), diluted 1 in 3000 in PBS. Membranes were stained with 4-chloro-1-naphthol.

\section{Preparation of bacterins}

Bacterial cells from mid-log phase broth culture were harvested by centrifugation, washed three times with PBS and resuspended to c. $10^{9}$ cells $/ \mathrm{ml}$ in $10 \mathrm{ml}$ of PBS containing formaldehyde $0.3 \%$. Suspensions were inactivated by stirring overnight at $4{ }^{\circ} \mathrm{C}$, and stored at $-20^{\circ} \mathrm{C}$ in small volumes.

\section{Preparation of porcine hyperimmune sera}

Antisera against $S$. pilosicoli (strain 1648), S. hyodysenteriae (type strain $\mathrm{B} 78^{\mathrm{T}}$ ) and $S$. innocens (type strain $\mathrm{B} 256^{\mathrm{T}}$ ) were prepared in three 4-week-old pigs. A blood sample was taken for serum, then each pig received $1.5 \mathrm{ml}$ of bacterin suspended in $1.5 \mathrm{ml}$ of Freund's complete adjuvant (Sigma) at two deep intramuscular sites in the neck. This was repeated 2 weeks later, then each pig was vaccinated weekly for 4 weeks with bacterin emulsified in Freund's incomplete adjuvant. Finally, $1.5 \mathrm{ml}$ of bacterin without adjuvant was given intravenously twice with a 1-week interval. Blood was collected by jugular puncture 1 week after the last immunisation, and the sera was harvested and stored in divided volumes at $-20^{\circ} \mathrm{C}$.

\section{Absorption of pig hyperimmune serum raised to S. pilosicoli}

Five $\mathrm{ml}$ of antiserum raised against $S$. pilosicoli strain 1648 were mixed with $2 \mathrm{ml}$ of pooled pellets of outer envelope proteins from both $S$. hyodysenteriae strain $\mathrm{B} 78^{\mathrm{T}}$ and $S$. innocens strain $\mathrm{B} 256^{\mathrm{T}}$ (c. $500 \mathrm{mg}$ of bacterial protein obtained from 1500-ml lots of fresh broth), incubated at $37^{\circ} \mathrm{C}$ in a waterbath for $30 \mathrm{~min}$ and then left overnight at $4^{\circ} \mathrm{C}$ on a rotary mixer. The serum was centrifuged at $15000 \mathrm{~g}$ for $10 \mathrm{~min}$, and the supernate was collected. The specificity of this absorbed serum was confirmed by Western blot analysis against outer envelope preparations from a range of strains of Serpulina spp. Where necessary the absorption was repeated several times until the serum reacted with a specific protein band present only in $S$. pilosicoli strains.

\section{Purification of a $72-k D a$ S. pilosicoli protein}

For the production both of a more specific polyvalent rabbit antiserum and subsequently of MAbs, outer envelope proteins from $S$. pilosicoli strain 1648 were prepared and separated by SDS-PAGE. A major protein band with a molecular mass of $c .72 \mathrm{kDa}$, previously identified as being specific for $S$. pilosicoli in Western blot analysis with absorbed pig antiserum, was excised and sliced into small pieces and the protein was extracted from it by electro-elution (BioRad electroeluter apparatus). The protein was precipitated by the addition of 10 volumes of absolute acetone at $4^{\circ} \mathrm{C}$ for $18 \mathrm{~h}$, centrifuged at $1000 \mathrm{~g}$ for $30 \mathrm{~min}$, resuspended in PBS, and the protein content was measured. The protein was subjected to SDS-PAGE and Western blot analysis with unabsorbed pig antiserum to $S$. pilosicoli to confirm its presence. The protein nature of the purified $72-\mathrm{kDa}$ band was confirmed by adding proteinase $\mathrm{K}(2 \mathrm{mg} / \mathrm{ml})$ in proteinase $\mathrm{K}$ buffer (150 mM Tris, $7 \mathrm{mM}$ EDTA, SDS $0.05 \%$ ), heating at $50^{\circ} \mathrm{C}$ for $2 \mathrm{~h}$, then subjecting this to SDS-PAGE and Western blot analysis with the absorbed pig antiserum.

\section{Preparation and absorption of a rabbit antiserum}

Rabbit antiserum was prepared against the purified protein in a 6-week old New Zealand White rabbit. The rabbit was inoculated with $1 \mathrm{ml}$ of purified protein $(50 \mu \mathrm{g} / \mathrm{ml})$ emulsified in $1 \mathrm{ml}$ of Freund's incomplete adjuvant and injected twice at two intramuscular sites at an interval of 14 days. One $\mathrm{ml}$ of the protein solution was then given intravenously at weekly intervals for a further 4 weeks. The rabbit was bled 1 week after the last immunisation and the serum was absorbed as for the porcine serum.

\section{Immunogold labelling of whole spirochaete cells}

Cultures of $S$. pilosicoli strain 1648 (positive control) and $S$. hyodysenteriae strain $\mathrm{B} 78^{\mathrm{T}}$ (negative control) were harvested by centrifugation of mid-log phase broth culture at $1000 \mathrm{~g}$ for $10 \mathrm{~min}$, and the cells were washed three times with $0.02 \mathrm{M} \mathrm{MgCl}_{2}$-PBS. Resuspended cells were fixed in Karnovsky's fixative for $2 \mathrm{~h}$ at room temperature, washed in PBS and suspended in $0.1 \mathrm{M}$ sodium cacodylate buffer $(\mathrm{pH} 7.2)$. The fixed cells were centrifuged at $1000 \mathrm{~g}$ for $10 \mathrm{~min}$ and suspended in $0.5 \mathrm{ml}$ of undiluted absorbed rabbit serum. Cells were incubated overnight at $4^{\circ} \mathrm{C}$, washed three times with $0.02 \mathrm{M} \mathrm{MgCl}_{2}$-PBS and treated with goat anti-rabbit IgG $10-\mathrm{nm}$ gold conjugate (Sigma) diluted 1 in 10 in PBS. After incubation at $30^{\circ} \mathrm{C}$ for $2 \mathrm{~h}$, the suspensions were washed three times in PBS. A drop of each suspension was placed on the surface of a Formvar-coated grid for $30 \mathrm{~s}$, blotted off, a drop of sodium phosphotungstate $1 \%$ was added for $30 \mathrm{~s}$, and then this was also blotted off. The grids were examined with a Phillips 301 transmission electron microscope.

\section{Production of MAbs}

MAbs were prepared as described previously [22], in this case with the purified electro-eluted $72-\mathrm{kDa}$ protein 
as immunogen. Hybridoma supernates were screened for specific antibody production in ELISA, with $100 \mu \mathrm{l}$ of purified $72-\mathrm{kDa}$ protein $(c .5 \mu \mathrm{g} / \mathrm{ml})$ in each well as the plate-coating antigen. The absorbance of the substrate in the well was read at $450 \mathrm{~nm}$. A positive to negative $\mathrm{OD}_{450}$ ratio of two or more was considered to be a positive reaction. Hybridomas giving a positive ELISA reading were cloned by limiting dilution, again tested by ELISA, and subsequently tested in Western blot analysis against outer envelope extracts to determine their specificity. MAbs C12 and M96 were selected for further study, and their isotype was determined with an ELISA-based mouse monoclonal isotyping kit (BioRad).

\section{Western blot and immunodot-blot assays}

Outer envelope preparations from all strains were tested blindly by Western blotting, as described previously and in an immunodot-blot assay, by the method of Hawkes et al. [27]. Briefly, for the immunodot-blot assay, suspensions of extracts in PBS (about $50 \mu \mathrm{g} / \mathrm{ml}$ ) were aspirated on to a nitrocellulose filter (Hybond-C extra, $0.45 \mu \mathrm{m}$ pore size; Amersham) with a dot-blot apparatus (BioRad). The membrane was soaked in skimmed milk powder 5\% in Tris-buffered saline (TBS, $\mathrm{pH}$ 7.5) for $1 \mathrm{~h}$ at room temperature with gentle agitation, washed with TBS twice for $5 \mathrm{~min}$ each, air dried and exposed to undiluted culture supernate at $4^{\circ} \mathrm{C}$ overnight. The membrane was incubated with a dilution of 1 in 3000 blotting grade HRP-conjugated goat antimouse serum in PBS, and developed with HRP-colour reagent. The reaction was stopped by transferring the membranes into distilled water, and positive reactions were indicated by the development of brown staining reactions. All assays were repeated at least twice, and the code was broken only when all results were obtained.

\section{Indirect fluorescent antibody test (IFAT)}

Spirochaete cultures were washed three times, diluted in PBS, placed on glass microscope slides at a density of c. 10 spirochaetes/high-powered light microscope field, air dried and fixed with cold acetone for $10 \mathrm{~min}$. The fixed cells were then treated with single drops of undiluted MAb M96 culture supernate, and each slide was coded before being incubated in a moist chamber at $37^{\circ} \mathrm{C}$ for $30 \mathrm{~min}$. After incubation, the smears were washed thoroughly three times with PBS for $5 \mathrm{~min}$ each, then incubated with $100 \mu$ l of a 1 in 80 dilution of fluorescein-conjugated goat-antimouse $\operatorname{IgG}+\mathrm{M}+\mathrm{A}$ (Capple Laboratories, Organon Teknika Corp, Durham, $\mathrm{NC}$, USA) in PBS at $37^{\circ} \mathrm{C}$ for $30 \mathrm{~min}$. After washing three times with PBS for $5 \mathrm{~min}$, the slides were covered with cold glycerol $90 \%$ solution in PBS and examined with an Olympus BH-2 incidence fluorescent microscope. Positive reactions were characterised by the presence of bright yellowish green fluorescence over the whole bacterial cells and were scored according to the brightness of the reaction $(+$, weak reactions; ++ , strong reactions; and +++ , very strong reactions). All assays were repeated at least twice, and the code was broken only when all the results were available.

\section{Results}

Identification of a 72-kDa outer envelope protein specific for $S$. pilosicoli

In SDS-PAGE gels stained with Coomassie blue, outer envelope protein preparations from the different species of intestinal spirochaetes contained a large number of polypeptide bands with a similar range of $M_{r}$ of 10 $112 \mathrm{kDa}$ (not shown). Polyclonal pig serum raised against whole cells of $S$. pilosicoli strain 1648 reacted in Western blot analysis with most of these proteins, including a prominent protein band at $c .72 \mathrm{kDa}$ which was the subject of subsequent investigation (Fig. 1). Similar reactions were observed when the separated proteins were treated with polyclonal pig sera raised against $S$. hyodysenteriae strain $\mathrm{B}^{\mathrm{T}} 8^{\mathrm{T}}$ or $S$. innocens strain $\mathrm{B} 256^{\mathrm{T}}$ (not shown). When the pig antiserum raised against $S$. pilosicoli strain 1648 was repeatedly cross-absorbed, eventually it recognised only the prominent protein band with a $\mathrm{M}_{\mathrm{r}}$ of $c .72 \mathrm{kDa}$ that was present in preparations from all the $S$. pilosicoli strains examined. This reactivity was absent from the other intestinal spirochaetes examined. With the homologous strain 1648 a number of other protein bands of lower $m_{r}$ also were observed in Western blot analysis (Fig. 2).

Before absorption, the rabbit serum raised against the electro-eluted $72-\mathrm{kDa}$ protein reacted with a large number of bands in all the outer envelope preparations. As with the pig serum, it could be made specific for the $72-\mathrm{kDa}$ band by cross-absorption (not shown).

Proteinase treatment of the $72-\mathrm{kDa}$ band before electrophoresis resulted in its disappearance from the stained gel.

\section{Immunogold labelling}

Immunogold-labelling particles were found loosely associated with the outer surface of $S$. pilosicoli strain 1648 (Fig. 3), whereas this reaction was completely absent when $S$. hyodysenteriae strain $\mathrm{B} 78^{\mathrm{T}}$ was used (not shown).

\section{Prodution, characterisation and use of MAbs}

Two MAbs, designated $\mathrm{C} 12$ and M96, that gave positive readings in the ELISA were selected for further study. Both reacted with kappa light chain and were of isotype IgG1. Unexpectedly, in Western blot analysis $\mathrm{C} 12$ recognised a protein band of c. $72 \mathrm{kDa}$ in outer envelope preparations from all 


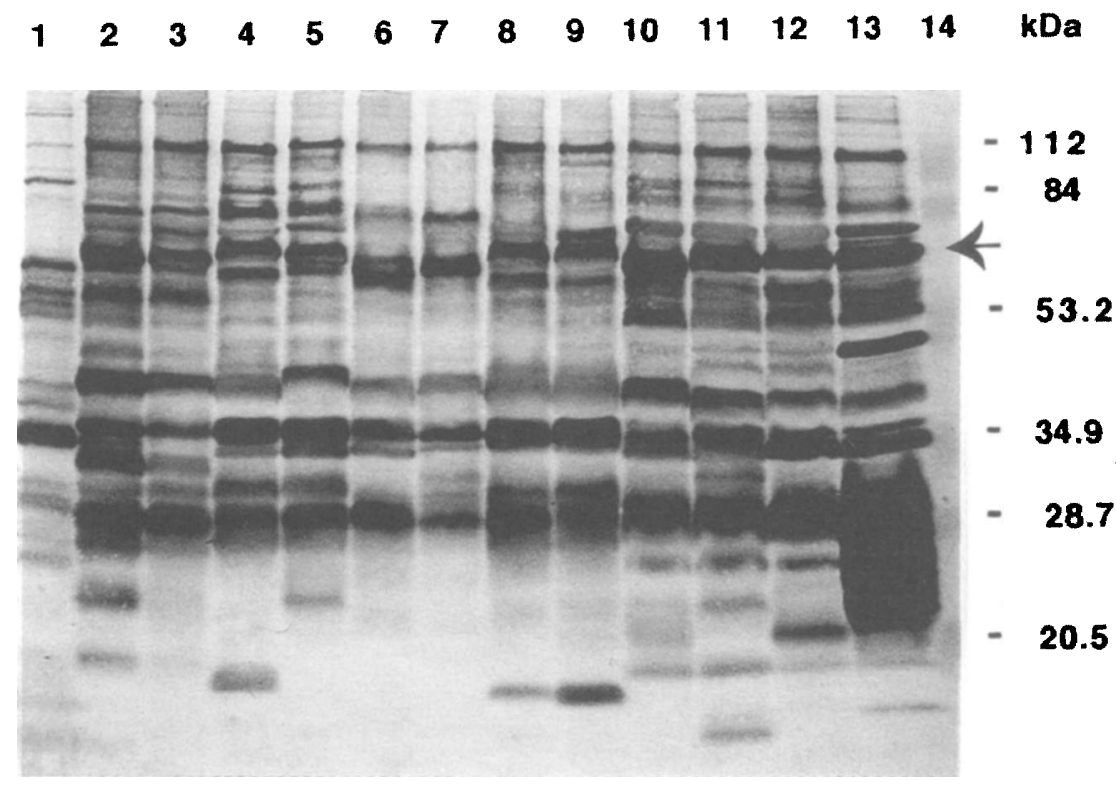

Fig. 1. Western blot analysis of Triton X-114 extracts from intestinal spirochaetes with a pig antiserum raised against $S$. pilosicoli strain 1648. Lane 1, B. aalborgi strain ATCC43994; 2, S. hyodysenteriae strain B204; 3, S. hyodysenteriae strain $\mathrm{B} 78^{\mathrm{T}} ; \mathbf{4}, S$. murdochii strain $56-160 ; 5, S$. murdochii strain $155-21 ; 6$, S. intermedia strain $889 ; 7, S$. intermedia strain PWS/A; 8, S. innocens strain 4/71; 9, S. innocens strain B256 ${ }^{\mathrm{T}} ; \mathbf{1 0 - 1 3}, S$. pilosicoli isolates from man $(10-11)$ and pigs $(12-13)$ : 10, WesB; 11, HRM2B; 12, 3295; 13, 1648; 14, $\mathrm{M}_{\mathrm{r}}$ markers $(\mathrm{kDa})$. The serum cross-reacted with preparations from all spirochaetes tested, but a prominent $72-\mathrm{kDa}$ band which was studied further was present in all the $S$. pilosicoli strains (lanes 10-13) (arrowed).

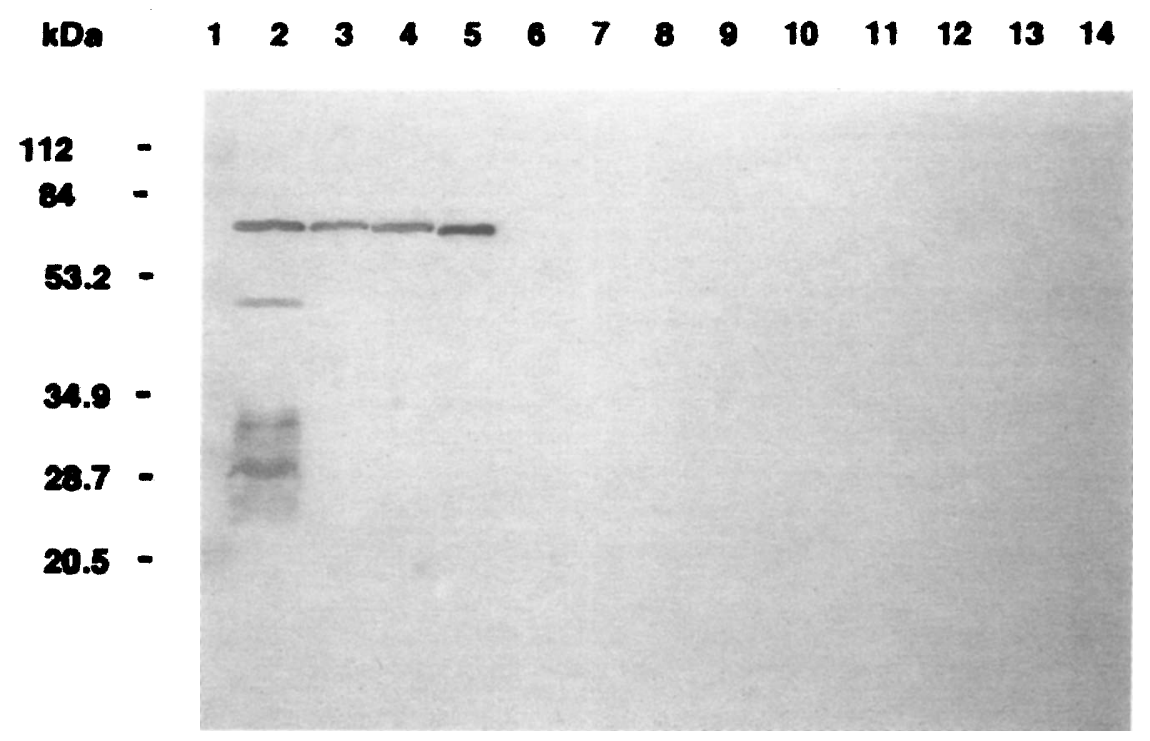

Fig. 2. Western blot analysis of Triton X-114 extracts from intestinal spirochaetes with a pig antiserum raised against $S$. pilosicoli strain 1648, absorbed with outer envelope protein extracts of $S$. hyodysenteriae strain $\mathrm{B} 78^{\mathrm{T}}$ and $S$ innocens strain $\mathrm{B} 256^{\mathrm{T}}$. Lane $1, \mathrm{M}_{\mathrm{r}}$ markers $(\mathrm{kDa}) ; 2-5, S$. pilosicoli isolates from pigs $(2,3)$ and man $(4,5): 2,1648$; 3, 3295; 4, HRM2B; 5, WesB; 6, S. innocens strain B256; 7, S. innocens strain 4/71; 8, S. intermedia strain PWS/A; 9, S. intermedia strain $889,10, S$. murdochii strain $155-21 ; 11, S$. murdochii strain $56-160 ; 12, S$. hyodysenteriae strain B 78,13, S. hyodysenteriae strain B204; 14, B. aalborgi strain ATCC43994.

the Serpulina spp., although it did not react with preparations from $B$. aalborgi (not shown). MAb M96 recognised a protein band at $c .80 \mathrm{kDa}$ in preparations of all S. pilosicoli strains tested, but did not react with any bands in preparations from the other intestinal spirochaetes (Fig. 4). In the immunodot-blot assay, MAb M96 again reacted with outer envelope preparations only from the $S$. pilosicoli strains (Table 1). In IFAT with MAb M96, $S$. pilosicoli strains gave strong surface fluorescence, whilst no specific fluorescence was detected with other intestinal spirochaetes (Table 1). 


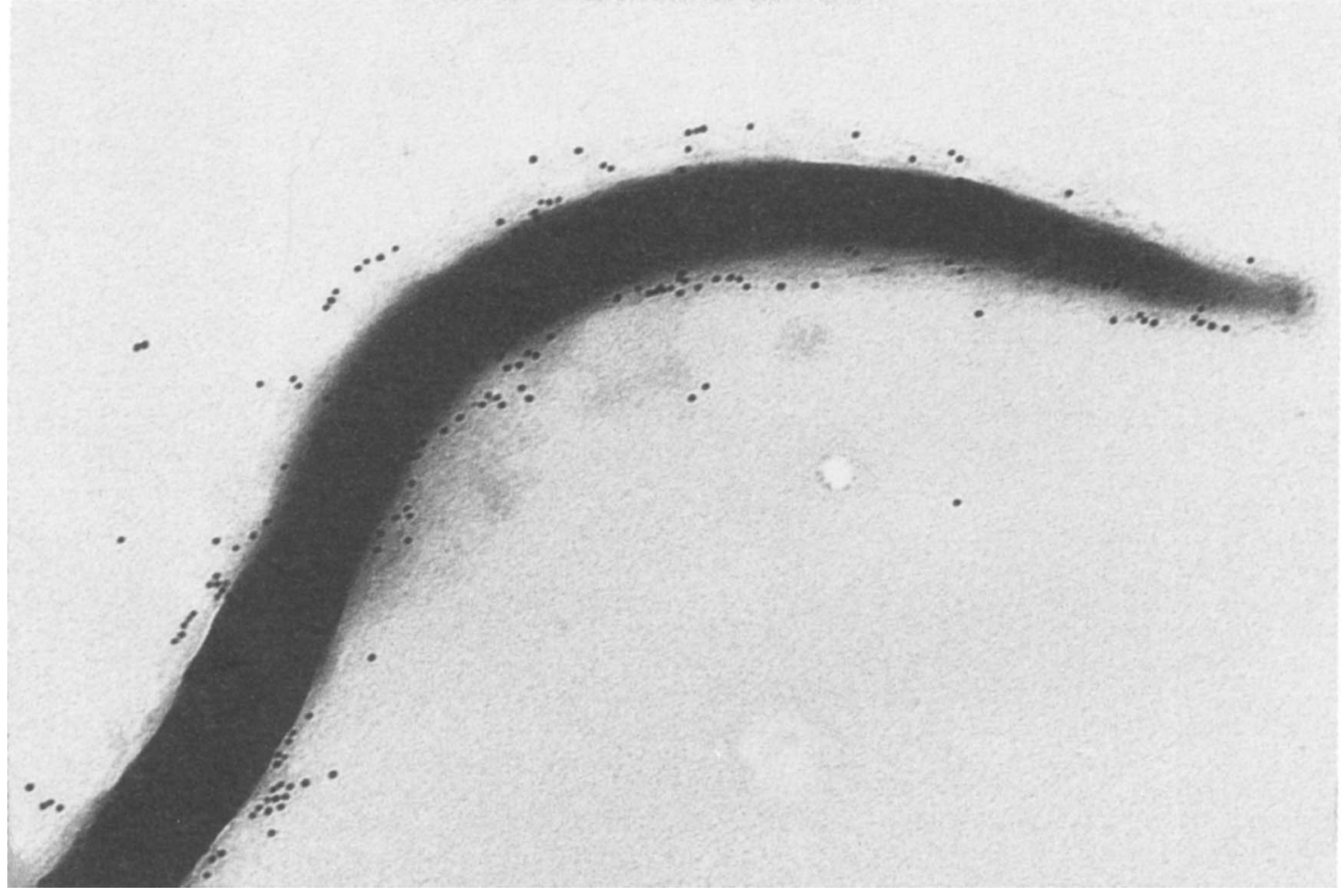

Fig. 3. Immunogold labelling of an intact cell of $S$. pilosicoli strain 1648 with a rabbit antiserum raised against a $72-$ $\mathrm{kDa}$ outer envelope protein and absorbed with outer envelope protein extracts of $S$. hyodysenteriae strain $\mathrm{B} 78^{\mathrm{T}}$ and $S$. innocens strain $\mathrm{B} 256^{\mathrm{T}}$. The outer cell surface location of the reactive epitope is shown.

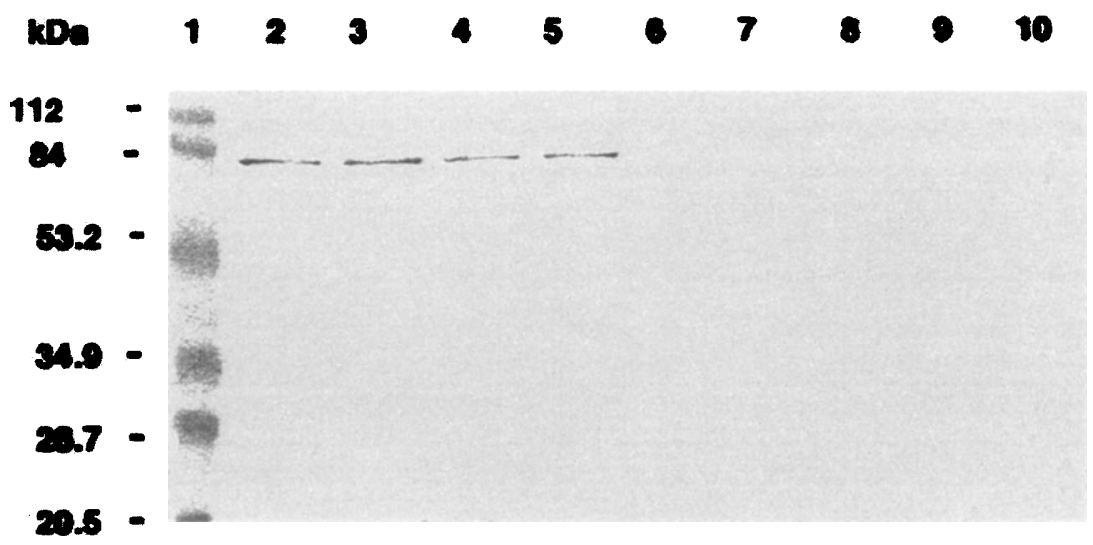

Fig. 4. Western blot analysis of MAb M96 with Triton X-114 outer envelope protein extracts of intestinal spirochaete strains. Lane 1, $\mathrm{M}_{\mathrm{r}}$ markers $(\mathrm{kDa}) ; 2-5, S$. pilosicoli isolates from pigs $(2,3)$ and man $(4,5): 2,1648 ; 3,3295 ; 4$, HRM2B; 5, WesB; 6, S. innocens strain B256 ; 7, S. intermedia strain PWS/A; 8, S. murdochii strain 155-21; 9, S. hyodysenteriae strain $\mathrm{B} 78^{\mathrm{T}} ; 10, B$. aalborgi strain ATCC 43994 .

\section{Discussion}

As in a previous study, SDS-PAGE analysis of Triton $\mathrm{X}$-114-extracted protein preparations from intestinal spirochaetes showed that these contained many bands [22]. Therefore, it seems likely that these preparations included proteins from the whole outer envelope and possibly some cytoplasmic components. However, a major protein with a $\mathrm{m}_{\mathrm{r}}$ of $c .72 \mathrm{kDa}$, which was unique to isolates of $S$. pilosicoli, was identified in the preparations by Western blot analysis with both absorbed polyclonal pig serum raised against whole $S$. pilosicoli cells and absorbed rabbit serum raised against the $72-\mathrm{kDa}$ protein. The absorption process apparently removed all antibody that was reactive to external proteins shared by other Serpulina spp. Immunogold staining in transmission electron microscopy demonstrated that the $72-\mathrm{kDa}$ protein was located on the outer surface of the intact cell, suggesting that it was part of the outer membrane. Its protein nature was confirmed by its disappearance after proteinase $\mathrm{K}$ treatment, although 
no attempt was made to determine whether it was glycosylated.

The absorbed rabbit serum produced here is a potentially useful reagent that could be used for diagnostic purposes and for further studies on the 72 $\mathrm{kDa}$ protein. Unfortunately, preparation of this serum is not particularly practical for widescale use. The absorption process reduces the antibody titre and is time-consuming; furthermore, the resultant sera are likely to be of variable titre and specificity. For this reason this study attempted to raise MAbs against the protein, as this might overcome many of these problems. Two MAbs that were both initially thought to be specific for the $72-\mathrm{kDa}$ protein of $S$. pilosicoli were obtained. Unfortunately it was subsequently found that the $72-\mathrm{kDa}$ protein band that $\mathrm{MAb} \mathrm{C12}$ reacted with was present in all Serpulina spp. examined (although not in B. aalborgi). Presumably, this common protein with the same $\mathrm{M}_{\mathrm{r}}$ as the $S$. pilosicoli-specific protein was also present in the electro-eluted material used to prepare both the rabbit serum and the MAbs. Although not specific for $S$. pilosicoli, MAb $\mathrm{C} 12$ might still be useful for differentiating intestinal spirochaetes of the genus Serpulina from other spirochaetes in the gut. Clearly it will be necessary to confirm the specificity of this $\mathrm{MAb}$ by screening it against other intestinal spirochaetes such as Treponema succinifaciens, as well as other enteric micro-organisms. Achacha and Mittal reported preparing Serpulina genus-specific MAbs after using whole cells of $S$. hyodysenteriae for immunisation [28]. These recognised common antigens of $S$. hyodysenteriae and $S$. innocens with $\mathrm{M}_{\mathrm{r}}$ in the range $26-45 \mathrm{kDa}$, but they were not tested against $S$. pilosicoli strains.

MAb M96 reacted with an $80-\mathrm{kDa}$ band in extracts of all $S$. pilosicoli strains examined. This protein was distinct from the original $72-\mathrm{kDa}$ protein and appeared to be a minor component in these extracts in comparison to the prominent $72-\mathrm{kDa}$ band. Nevertheless, the $80-\mathrm{kDa}$ band was $S$. pilosicoli-specific, and MAb M96 was effective for identification in Western blot analysis and in an immunodot-blot assay with outer envelope preparations. MAb M96 also reacted specifically in a whole-cell IFAT. This reactivity suggested that the reactive epitope was located externally, although immunogold transmission electron microscopy was not conducted to confirm this. MAb M96 correctly identified a range of $S$. pilosicoli strains from man, pigs, dogs and chikens, and hence is a potentially important reagent for diagnostic purposes, and for future studies on the outer envelope of $S$. pilosicoli.

This work was funded by a grant from Murdoch University. I.W.M.T was in receipt of a postgraduate research scholarship from the Australian International Development Assistance Bureau. Thanks are due to Sophy Oxberry, B. J. Lee and D. J. Trott for technical assistance.

\section{References}

1. Stanton TB. Proposal to change the genus designation Serpula to Serpulina gen. nov. containing the species Serpulina hyodysenteriae comb. nov. and Serpulina innocens comb. nov. Int J Syst Bacteriol 1992; 42: 189-192.

2. Trott DJ, Stanton TB, Jensen NS, Duhamel GE, Johnson JL Hampson DJ. Serpulina pilosicoli sp. nov.: the agent of porcine intestinal spirochetosis. Int $J$ Syst Bacteriol 1996; 46; 206-215.

3. Stanton TB, Fournie-Amazouz E, Postic D et al. Recognition of two new species of intestinal spirochaetes: Serpulina intermedia sp. nov. and Serpulina murdochii sp. nov. Int $J$ Syst Bacteriol 1997; 47: 1007-1012.

4. Taylor DJ, Simmons JR, Laird HM. Production of diarrhoea and dysentery in pigs by feeding pure cultures of a spirochaete differing from Treponema hyodysenteriae. Vet Rec 1980; 106: 326-332.

5. Hampson DJ, Trott DJ. Intestinal spirochaetal infection of pigs: an overview and an Australian perspective. In: Hennessy DP, Cranwell PD (eds) Manipulating pig production V. Werribee, Victoria, Australia, Australasian Pig Science Association. 1995; $139-169$.

6. Duhamel GE. Porcine colonic spirochaetosis caused by Serpulina pilosicoli. PIGS-Misset International 1996; 12: 10-12.

7. Fellstrom C, Petterson B, Johansson KE, Lurdehein N, Gunnarsson A. Prevalence of Serpulina species in relation to diarrhea and feed medication in pig-rearing herds in Sweden. Am J Vet Res 1996; 57: 807-811.

8. Andrews JJ, Hoffman LJ. A porcine colitis caused by a weakly beta-hemolytic treponema (Treponema innocens?). Proceedings of the Annual Conference of the American Association for Vetrinary Laboratory Diagnosis. Nashville, Tennessee, USA, 1982; 395-402.

9. Jacques M, Girard C, Higgins R, Goyette G. Extensive colonization of the porcine colonic epithelium by a spirochete similar to Treponema innocens. J Clin Microbiol 1989; 27 : 1139-1141.

10. Girard C, Lemarchand T, Higgins R. Porcine colonic spirochetosis: a restrospective study of eleven cases. Can Vet $J$ 1995; 36: 291-294.

11. Harland WA, Lee FD. Intestinal spirochaetosis. $B M J 1967 ; 3$ : $718-719$.

12. Lee FD, Kraszweski A, Gordon J, Howie GR, McSeveney D, Harland WA. Intestinal spirochaetosis. Gut 1971; 12: 126-133.

13. Turek JJ, Meyer RC. Studies on a canine intestinal spirochete: scanning electron microscopy of canine colonic mucosa. Infect Immun 1978; 20: 853-855.

14. Duhamel GE, Muniappa N, Mathieson MR et al. Certain canine weakly beta-hemolytic intestinal spirochetes are phenotypically related to spirochetes associated with human and porcine intestinal spirochetosis. J Clin Microbiol 1995; 33: 2212-2215

15. Trempel DW, Jensen NS, Hoffman LJ. Cecal spirochetosis in commercial laying hens. Avian Dis 1994; 38: 895-898.

16. Trott DJ, McLaren AJ, Hampson DJ. Pathogenicity of human and porcine intestinal spirochetes in day-old specific pathogen free chicks: an animal model of intestinal spirochetosis. Infect Immun 1995; 63: 3705-3710.

17. Lee JI, Hampson DJ. Genetic characterisation of intestinal spirochaetes and their association with disease. $J \mathrm{Med}$ Microbiol 1994; 40: 365-371.

18. Atyeo RF, Oxberry SL, Hampson DJ. Pulsed-field gel electrophoresis for sub-specific differentiation of Serpulina pilosicoli (formerly "Anguillina coli"). FEMS Microbiol Lett 1996; 141: 77-81.

19. Trott DJ, Stanton TB, Jensen NS, Hampson DJ. Phenotypic characteristic of Serpulina pilosicoli the agent of intestinal spirochaetosis. FEMS Microbiol Lett 1996; 142: 209-214.

20. Park NY, Chung CY, McLaren AJ, Atyeo RF, Hampson DJ. Polymerase chain reaction for detection of human and porcine spirochaetes recovered from cases of intestinal spirochaetosis. FEMS Microbiol Lett 1995; 125: 225-230.

21. Fellstrom C, Gunnarsson A. Phenotypical characterisation of intestinal spirochaetes from pigs. Res Vet Sci 1995; 59: 1-4.

22. Lee BJ, Hampson DJ. A monoclonal antibody reacting with the cell envelope of spirochaetes isolated from cases of intestina spirochaetosis in pigs and humans. FEMS Microbiol Lett 1995; 136: $179-184$ 
23. Lee JI, Hampson DJ, Lymbery AJ, Harders SJ. The porcine intestinal spirochaetes: identification of new genetic groups. Vet Microbiol 1993; 34: 273-285.

24. Hovind-Hougen $\mathrm{K}$, Anderson AB, Nielsen $\mathrm{RH}$ et al. Intestinal spirochetosis: morphological characterization and cultivation of the spirochete Brachyspira aalborgi gen, nov., sp. nov. J Clin Microbiol 1982; 16: 1127-1136.

25. Kunkle RA, Harris DL, Kinyon JM. Autoclaved liquid medium for propagation of Treponema hyodysenteriae. J Clin Microbiol 1986; 24: 669-671.
26. Towbin H, Staehelin T, Gordon J. Electrophoretic transfer of proteins from polyacrylamide gels to nitrocellulose sheets: procedure and some applications. Proc Natl Acad Sci USA 1979; 76: $4350-4354$

27. Hawkes R, Niday E, Gordon J. A dot-immunobinding assay for monoclonal and other antibodies. Anal Biochem 1982; 119 $669-671$.

28. Achacha M, Mittal KR. Identification and characterization of genus-specific epitopes of Serpulina species using monoclonal antibodies. Vet Microbiol 1996; 48: 73-85. 